\title{
Immobilized Metal Affinity Chromatography
}

National Cancer Institute

\section{Source}

National Cancer Institute. Immobilized Metal Affinity Chromatography. NCI Thesaurus.

Code C161789.

A method to purify proteins or peptides from a mixture that leverages their affinity to positively charged ions immobilized on NTA-agarose beads. 